\title{
Impact of iodination on thyroid pathology in Africa
}

\author{
O E Okosieme
}

J R Soc Med 2006;99:396-401

\section{INTRODUCTION}

Thyroid disorders are common worldwide. ${ }^{1}$ In Africa, dietary iodine deficiency is the major determinant of thyroid pathology, resulting in a spectrum of iodine deficiency disorders, including goitres, hypothyroidism and mental retardation. ${ }^{2}$ Of these, mental retardation poses the most severe threat to socioeconomic wellbeing; thus, its prevention has been the focus of current global efforts towards sustainable iodine sufficiency. ${ }^{3}$ At least 350 million Africans are at risk of iodine deficiency. ${ }^{4}$ According to World Health Organization (WHO) estimates, goitres are present in $28.3 \%$ of the African population, ${ }^{4}$ and approximately $25 \%$ of the global burden of iodine deficiency as measured by disability-adjusted life years (DALYs) occurs in Africa. ${ }^{5}$ The demands of communicable diseases, coupled with the challenges of poverty, civil conflicts and fragile political structures, have in the past frustrated efforts at eliminating iodine deficiency in Africa. ${ }^{6}$ However, recent decades have seen remarkable improvements in iodine nutrition through salt iodination in the continent. ${ }^{7}$ The effect of these developments on the pattern of thyroid gland disease are beginning to unravel and will be relevant to the strategies for extending the present gains. In this article, I examine the impact of recent progress in iodine nutrition on the epidemiology of thyroid gland pathology in Africa.

\section{METHODS}

I searched Medline references using the term 'Africa' in combination with various search phrases related to thyroid disease: thyroid, goitre, hyperthyroidism, hypothyroidism, thyroid autoimmunity, thyroiditis, thyroid cancer and iodine. A further query was performed using the individual names of different countries in Africa. In addition, I consulted websites of the International Council for the Control of Iodine Deficiency Disorder (ICCIDD), WHO, and the United Nations Children's Fund (UNICEF).

\section{HISTORICAL ASPECTS}

Thyroid disorders have been recognized in Africa since olden times. Indigenous terms for thyroid swellings exist

Clinical Research Fellow, Centre for Endocrine and Diabetes Science, School of Medicine, Cardiff University, Cardiff, UK locally and goitres have featured in sculptures dating back centuries. ${ }^{8}$ The historian, Leo Africanus, observed tribes with goitres around Timbuktu in $1550 .{ }^{9}$ Centuries later, the Scottish surgeon Mungo Park would comment on the occurrence of goitres in his West African expeditions. ${ }^{9}$ By the mid-20th century, goitres were clearly endemic in virtually every part of the continent and it had become apparent that iodine deficiency was a significant public health problem in the region. ${ }^{9}$ By this period, the detrimental effects of iodine deficiency on fetal development had been established in other parts of the world. Studies in Papua New Guinea, in the 1960s had clearly shown that iodine supplementation was effective in preventing brain damage. ${ }^{10}$ In 1983, Hetzel introduced the term iodine deficiency disorders, thus shifting the emphasis away from the benign neck swelling to encompass the more serious and wide-ranging effects of iodine deficiency on growth and development. ${ }^{2}$ The ICCIDD was founded soon afterwards in 1985, as an expert consultative group to oversee the control and monitoring of iodine deficiency disorders at regional and international levels. ${ }^{11}$

\section{DEVELOPMENTS IN IODINE NUTRITION}

For most of the period before the 1990s, progress in Africa remained slow; prevention of iodine deficiency was low on the priorities of regional governments, structured programmes were lacking, and iodine supplementation was often approached erratically. As a result, this era saw only modest improvements in iodine intake. The introduction of formal iodine deficiency prevention programmes in the 1990s marked a turning point in the drive towards sustainable iodine sufficiency in Africa. In 1990, the World Summit for Children endorsed a resolution aimed at the virtual elimination of iodine deficiency worldwide. ${ }^{12}$ Through joint efforts by ICCIDD, WHO, UNICEF, and individual regional authorities, a strategy of universal salt iodination was promoted within the region. Iodized salt has since been made available to $62 \%$ of households ${ }^{7}$ and iodine sufficiency has thus been attained in at least 20 African countries, representing more than half the entire continent's population (Figure 1, Table 1). ${ }^{4}$ Despite these gains, however, at least 350 million of the population remain at risk of iodine deficiency disorders. ${ }^{4}$ Within iodine sufficient African countries, pockets of severe deficiency 


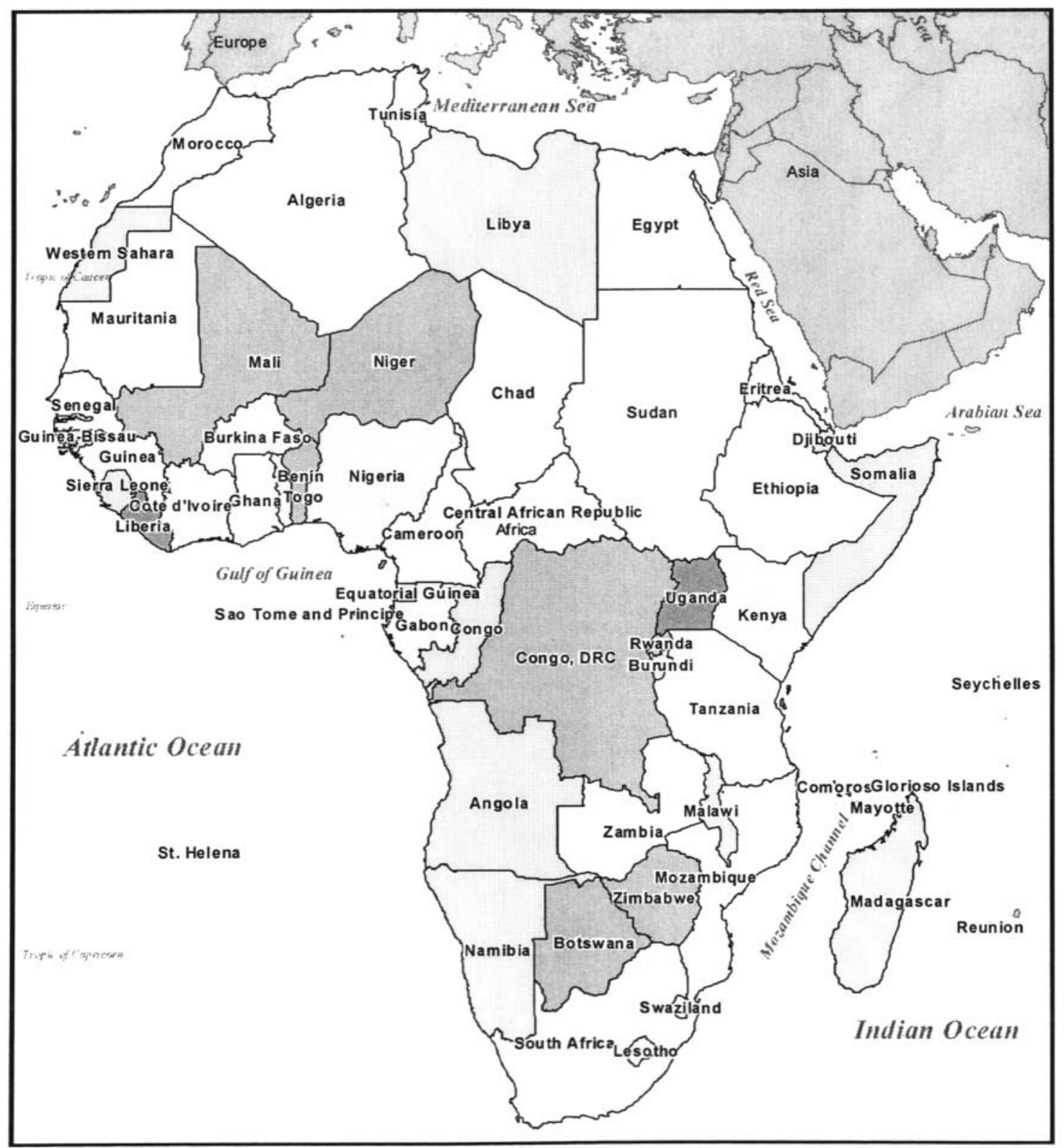

Figure 1 lodine nutrition in Africa [data source: WHO Global Database on lodine Deficiency, Ref. 4]. Median urinary iodine (mcg/L) $\square$ Moderate deficiency: 20-49; $\square$ mild deficiency 50-99; $\square$ optimal: 100-199; $\square$ more than adequate: 200-299; $\square$ excess: >299; $\square$ status uncertain

persist and vulnerable population sub-groups like neonates, toddlers and pregnant women continue to be in danger of iodine deficiency disorders. ${ }^{13,14}$ Nonetheless, the progress in recent years clearly indicates that iodine sufficiency is truly within reach in Africa.

\section{EVOLVING DISEASE PATTERNS}

There is compelling evidence that the pattern of thyroid disorders in a population is dependent on environmental iodine intake. ${ }^{15}$ Iodine deficiency disorders abound in areas with inadequate iodine intake while autoimmune thyroid disorders are rare in iodine deficiency but become prevalent with transition to iodine sufficiency. ${ }^{16}$ Monitoring disease patterns in Africa has proved challenging in the absence of
Table 1 Number of African countries in different categories of iodine nutrition, based on urinary iodine excretion [data source: WHO Global Database on lodine Deficiency, Ref. 4]

\begin{tabular}{lcc}
\hline Degree of iodine nutrition & $\begin{array}{l}\text { Median urinary } \\
\text { iodine (mcg/L) }\end{array}$ & $\begin{array}{l}\text { No. of African } \\
\text { countries }\end{array}$ \\
\hline Severe iodine deficiency & $<20$ & 0 \\
Moderate iodine deficiency & $20-49$ & 6 \\
Mild iodine deficiency & $50-99$ & 8 \\
Optimal iodine nutrition & $100-199$ & 11 \\
More than adequate iodine & $200-299$ & 7 \\
nutrition & & \\
Excess iodine intake & 300 & 2 \\
No data & & 12 \\
\end{tabular}


J O U R N A L OF THE ROYAL SOCIETY OF MEDICINE Volume 99 August 2006

Table 2 Total goitre prevalence in African countries before and after salt iodination programmes

\begin{tabular}{|c|c|c|c|c|c|c|c|c|c|c|}
\hline \multirow[b]{2}{*}{ Country } & \multicolumn{5}{|c|}{ Pre iodization } & \multicolumn{5}{|c|}{ Post iodization } \\
\hline & Goitre & Year & $\begin{array}{l}\text { Sample } \\
\text { size }\end{array}$ & $\begin{array}{l}\text { Population } \\
\text { age (years) }\end{array}$ & $\begin{array}{l}\text { Type of } \\
\text { survey }\end{array}$ & Goitre & Year & $\begin{array}{l}\text { Sample } \\
\text { size }\end{array}$ & $\begin{array}{l}\text { Population } \\
\text { age (years) }\end{array}$ & $\begin{array}{l}\text { Type of } \\
\text { survey }\end{array}$ \\
\hline Chad & 63 & 1993 & 1171 & $10-20$ & $\begin{array}{l}\text { National } \\
\text { (Ref. 23) }\end{array}$ & 24 & 2002 & 1024 & $7-12$ & $\begin{array}{l}\text { National } \\
\text { Ref. 24) }\end{array}$ \\
\hline Lesotho & 17.5 & 1993 & 323 & $6-16$ & $\begin{array}{l}\text { National } \\
\text { (Ref. 25) }\end{array}$ & 4.9 & 1999 & 500 & $10-14$ & $\begin{array}{l}\text { Sub-national } \\
\text { (Ref. 26) }\end{array}$ \\
\hline South Africa & 25.6 & 1995 & 565 & $\begin{array}{l}12.6 \\
\text { (mean) }\end{array}$ & $\begin{array}{l}\text { Sub-national } \\
\text { (Ref. 27) }\end{array}$ & 28 & 1996 & 536 & $\begin{array}{l}12.5 \\
\text { (mean) }\end{array}$ & $\begin{array}{l}\text { Sub-national } \\
\text { (Ref. 27) }\end{array}$ \\
\hline Nigeria & 29 & 1995 & 590 & $6-14$ & $\begin{array}{l}\text { Sub-national } \\
\text { (Ref. 28) }\end{array}$ & $2.9-33.3$ & 1998 & 2372 & $8-12$ & $\begin{array}{l}\text { Sub-national } \\
\text { (Ref. 29) }\end{array}$ \\
\hline Côte d'Ivoire & 45 & 1997 & 419 & $5-14$ & $\begin{array}{l}\text { Sub-national } \\
\text { (Ref. 30) }\end{array}$ & 29 & 2001 & 526 & $5-14$ & $\begin{array}{l}\text { Sub-national } \\
\text { (Ref. 30) }\end{array}$ \\
\hline
\end{tabular}

comprehensive biomedical information. Goitre surveys in children are frequently conducted in schools within accessible locations. The occurrence of other thyroid disorders is extrapolated from hospital case records and histopathology reviews. While providing useful information, these methods exclude large rural populations who lack access to health and educational facilities. These limitations notwithstanding, several trends in disease pattern have become apparent in recent decades.

\section{Endemic goitre}

Goitre due to dietary iodine deficiency is by far the most commonly observed thyroid disorder in Africa. ${ }^{17-19}$ The majority of affected people live within subsistence agricultural systems, commonly in mountainous regions which have been deprived of iodine by leaching of the soil. Goitrogens in local foods like cassava and millet accentuate the effects of iodine deficiency ${ }^{20}$ and other micronutrient deficiencies such as selenium also play a role in the development of goitres. ${ }^{21}$ The prevalence of goitres varies widely but may be as high as $85 \%$ in children in some areas. ${ }^{22}$ Recent improvements in iodine intake have led to reductions in goitre prevalence (Table 2) but goitres prevail in communities who continue to rely exclusively on home grown crops for nutrition. Children, females and pregnant women remain disproportionately affected. Recent studies have shown total goitre rates of close to a $100 \%$ in pregnant women, even in areas within countries with iodine sufficiency status. ${ }^{13,14}$

\section{Endemic cretinism}

The extreme form of iodine deficiency, endemic cretinism has been well characterized in Central Africa, where up to myxoedematous form of cretinism is highly prevalent in this population and hypothyroidism is seen in as much as a quarter of children in endemic areas. ${ }^{32}$ This pattern contrasts with other parts of the world where the neurological variety, characterized by mental deficiency, deaf mutism and spastic diplegia prevails. ${ }^{33}$ However, gross neurological defects are also seen in African populations and were described in $10 \%$ of patients with cretinism in the Kivu area of Democratic Republic of Congo. ${ }^{33}$ Less obvious disorders of cognition and intellect in infancy and childhood are likely to be even more widespread and to potentially constitute a greater burden on the economic output of affected communities. An analysis in Sierra Leone estimates that the future five-year productivity losses in the country, resulting from intellectual impairment associated with iodine deficiency would be in excess of US $\$ 42.5$ million. ${ }^{34}$

\section{lodine-induced thyrotoxicosis}

Thyrotoxicosis may occur in chronically iodine deficient individuals who are exposed to sharp increases in iodine intake. ${ }^{35}$ It is more likely in older patients with longstanding thyroid nodules. Toxic change in such nodules may be accompanied by biochemical or clinically overt thyrotoxicosis. Death from cardiac failure and arrhythmias may occur. ${ }^{35}$ Between 1991 and 1995, a sudden rise in the incidence of thyrotoxicosis was noted by physicians in Harare, Zimbabwe. The majority of these patients had toxic nodular goitres and 14 deaths were recorded. ${ }^{36}$ Likewise, biochemical thyrotoxicosis was diagnosed in 14 of 191 patients with goitres in Kivu, a previously iodine deficient area of Northern Zaire. ${ }^{37}$ These incidents followed the introduction of iodized salt to both countries. A multicentre study subsequently conducted by a team of seasoned 


\begin{tabular}{|c|c|c|c|c|c|c|c|}
\hline \multirow[b]{2}{*}{ Country } & \multirow[b]{2}{*}{ Period of study } & \multicolumn{4}{|c|}{ Histological type of cancer } & \multirow[b]{2}{*}{ Sample size } & \multirow[b]{2}{*}{ Reference } \\
\hline & & Follicular & Papillary & Medullary & Anaplastic & & \\
\hline Capetown, South Africa & $1952-1975$ & 31 & 27 & 4 & 10 & 254 & Selzer et al. (Ref. 49) \\
\hline Ibadan, Nigeria & $1957-1970$ & 60 & 14 & 0 & 10 & 109 & Olurin et al. (Ref. 18) \\
\hline Ibadan, Nigeria & $1965-1984$ & 45 & 45 & 5 & 4 & 137 & Thomas et al. (Ref. 50) \\
\hline Nairobi, Kenya & 1968-1973 & 55 & 30 & 0 & 15 & 20 & Gitau et al. (Ref. 19) \\
\hline Algiers, Algeria & $1966-1981$ & 36 & 39 & 4 & 16 & 385 & Bakiri et al. (Ref. 51) \\
\hline Khartoum, Sudan & 1982-1989 & 42 & 22 & 2 & 21 & 112 & Omran et al. (Ref. 52) \\
\hline Algiers, Algeria & $1982-1991$ & 40 & 46 & 4 & 8 & 615 & Bakiri et al. (Ref. 51) \\
\hline Ile-Ife, Nigeria & 1983-1993 & 69 & 11 & 6 & 3 & 36 & Lawal et al. (Ref. 53) \\
\hline Addis Ababa, Ethiopia & 1994-1998 & 16 & 77 & 6 & 2 & 64 & Tsegaye et al. (Ref. 17) \\
\hline Durban, South Africa & 1990-1997 & 68 & 16 & 13 & 3 & 100 & Mulaudzi et al. (Ref. 54) \\
\hline
\end{tabular}

international researchers established that the problem was likely transient and not widespread on the continent. ${ }^{38}$ Accordingly, recommended levels of salt iodization in the region have been reduced to $20-40 \mathrm{ppm} .{ }^{38}$

\section{Graves' disease}

Graves' disease is the commonest cause of hyperthyroidism in iodine-replete parts of world. ${ }^{1}$ The average annual incidence of Graves' disease in Whickham, UK, is approximately $80 / 100000$ for females. ${ }^{39}$ In Johannesburg, the incidence is about 10 times less $(8.75 / 100000$ per year). ${ }^{40}$ Graves' disease was believed to be rare in Africa, based on the early experience of physicians in the region. ${ }^{41}$ However, it is now more frequently reported across the continent. In South Africa, a 60\% rise in its incidence was observed over an 11 -year period. ${ }^{40}$ This was most apparent in iodine sufficient urban dwellers, a significant proportion of who were recent migrants from iodine deficient areas. ${ }^{40}$ The clinical presentation of Graves' disease appears no different from elsewhere; females are more commonly affected, ${ }^{40}$ ophthalmopathy is common, ${ }^{42}$ and thyroidstimulating hormone-receptor antibodies are present in over $80 \%$ of patients. ${ }^{43}$ However, as a result of late presentations, a disproportionate amount of cardiac complications are seen. ${ }^{44}$ The approach to management is dictated by existing local facilities. Radioiodine is not widely available so the options vary between medical and surgical treatments. Surgery is sometimes the more practical alternative due to the unaffordable cost and lengthy hospital follow up of medical treatment.

\section{Autoimmune hypothyroidism}

The spectrum of autoimmune hypothyroidism includes Hashimoto's thyroiditis, primary myxoedema and post- partum thyroiditis. These conditions form the bulk of the thyroid physician's workload in iodine sufficient countries. ${ }^{1}$ The reverse is seen in Africa where autoimmune hypothyroidism is rarely encountered, either by clinicians ${ }^{18,19}$ or histopathologists. ${ }^{17}$ In striking contrast to Graves' disease, the incidence of autoimmune hypothyroidism in African blacks does not appear to have been amplified by improvements in iodine intake. One possible explanation for this discrepancy may lie with recognition. Unlike Graves' disease, autoimmune hypothyroidism is particularly difficult to diagnose on clinical grounds alone and, in the absence of sensitive laboratory facilities, it is not improbable that cases will be missed. However, it is likely that genetic factors also contribute to the relative rarity of thyroid autoimmunity in Africans. Black Africans have lower levels of thyroid antibodies than Africans of European or Asian descent. ${ }^{40}$ Interestingly, induction of thyroid antibodies following iodine supplementation has been reported in Europe $^{45}$ and Asia, ${ }^{46}$ but this has not been the case in Africa. ${ }^{47}$ Prospective population-based studies are needed to determine the true occurrence of autoimmune hypothyroidism in Africans.

\section{Thyroid malignancy}

The histology of thyroid cancers in a population is dependent on the ambient iodine intake. A high proportion of aggressive follicular and anaplastic tumours are seen in iodine deficiency while the more benign papillary type is common in iodine-rich populations. ${ }^{48}$ Follicular carcinoma is the predominant histological variety in Africa (Table 3). This pattern has prevailed over the decades, suggesting persisting iodine deficiency. However, the incidence of anaplastic carcinoma appears to be falling and other reports suggest a relative rise in papillary tumours, implying 
improved iodination on the other hand (Table 3). This mixed picture may thus reflect a transitory period in iodine nutrition coupled with regional variations in iodine status. Nonetheless, it is doubtful if reversals in cancer histology will necessarily translate to improvements in prognosis in Africa. Advanced disease at presentation and poor follow up are common in Africans with limited access to health services. ${ }^{52,55}$ A study in Algeria showed that survival rates in patients with differentiated thyroid carcinoma were related to the level of health service provision rather than the effects of iodine status on cancer histology. ${ }^{51}$

\section{FUTURE CHALLENGES}

If the present momentum is anything to go by, then iodine sufficiency could be attained in most parts of the continent within the next decade. However, maintenance of these gains will prove challenging in an African climate marred by wars, famine and political instability. Experience from iodine sufficient countries has shown that interruption of iodine replacement is rapidly followed by relapse of iodine deficiency. ${ }^{56}$ Sustained political will and robust legislative structures will be required to ensure the continued availability of iodized salt. With improvements in iodine nutrition, the pattern of thyroid disorders is expected to continue evolving. It remains to be established if autoimmune hypothyroidism will emerge in the stead of endemic goitres as has happened in parts of Europe. However, the primary goal of salt iodination remains the prevention of brain damage due to iodine deficiency; therefore the risks associated with iodine replacement in the African population are clearly outweighed by its benefits and should not deter continued iodine prophylaxis. Nonetheless, the possibility of side effects calls for increased vigilance in monitoring the effects of iodination.

\section{CONCLUSION}

Despite incomplete biomedical information, it is apparent that the pattern of thyroid disorders in Africa is evolving with increasing iodine sufficiency. Total goitre prevalence has fallen in populations with salt iodination programmes. However, pockets of goitres persist, and more subtle effects of iodine deficiency on cognition and intellect in childhood are likely to be still widespread. The incidence of Graves' disease is rising, particularly in African populations exposed to sharp increases in iodine consumption. In addition, transient iodide-induced thyrotoxicosis was potentially fatal in two African countries. While consolidating the present gains, salt iodination programmes must now target poor rural populations, and vulnerable sub-groups including pregnant women and children who remain at significant risk clinicians in the region will need to be adequately resourced to identify and manage emerging thyroid disorders.

\section{Competing interests None declared.}

\section{REFERENCES}

1 Vanderpump MPJ, Tunbridge WMG. The epidemiology of thyroid diseases. In: Braverman LE, Utiger RD, eds The Thyroid. 7th ed. Philadelphia: Lippincott Raven, 1996:474-82

2 Hetzel BS. Iodine deficiency disorders (IDD) and their eradication. Lancet 1983;2:1126-9

3 Maria Andersson, Bahi Takkouche, Ines Egli, Henrietta E. Allen, \& Bruno de Benoist. Current global iodine status and progress over the last decade towards the elimination of iodine deficiency. Bull World Health Organ 2005;83:518-25

4 World Health Organization. Iodine Status Worldwide: WHO Global Database on Iodine Deficiency. Geneva: WHO, 2004:1-58. (www.whqlibdoc.who.int/publications/2004/9241592001.pdf)

5 World Health Organization. Annex 3: Burden of disease in DALYs by cause, sex and mortality stratum in WHO regions, estimates for 2001. In: The World Health Report. Geneva: WHO, 2002:192-7. (www.who.int/whr/2002/whr2002_annex3.pdf)

6 Ekpechi OL. Iodine deficiency disorders in Africa. In: Hetzel BS, Dunn JT, Stanbury JB, eds The Prevention and Control of Iodine Deficiency Disorders. Amsterdam: Elsevier Science Publishers (Biomedical division), 1987:219-36

7 ICCIDD. IDD Newsletter 2003;19(1):1-6

8 Wells C. Goitre in two African sculptures. Med Hist 1968;12: $89-91$

9 Kelly FC, Snedden WW. Prevalence and geographical distribution of endemic goitre. Bull World Health Organ 1958;18:5-173

10 Pharoah PO, Buttfield IH, Hetzel BS. Neurological damage to the fetus resulting from severe iodine deficiency during pregnancy. Lancet 1971; $1: 308-10$

11 Hetzel BS, Eliminating iodine deficiency disorders - the role of the International Council in the global partnership. Bull World Health Organ 2002;80:410-13

12 www.unicef.org/wsc/goals.htm (accessed April 2005)

13 Adesunkanmi AR, Makinde ON. Goitre prevalence in pregnant women attending antenatal clinic in a teaching hospital. $J$ Obstet Gynaecol 2003;23:156-9

14 Torheim LE, Granli GI, Sidibe CS, Traore AK, Oshaug A. Women's iodine status and its determinants in an iodine-deficient area in the Kayes region, Mali. Public Health Nutr 2005;8:387-94

15 Laurberg P, Pedersen KM, Hreidarsson A, Sigfusson N, Iversen E, Knudsen PR. Iodine intake and the pattern of thyroid disorders: a comparative epidemiological study of thyroid abnormalities in the elderly in Iceland and in Jutland, Denmark. J Clin Endocrinol Metab 1998;83:765-9

16 Doufas AG, Mastorakos G, Chatziioannou S, Tseleni-Balafouta S, Piperingos G, Boukis MA, Mantzos E et al. The predominant form of non-toxic goiter in Greece is now hyroiditis. Eur $J$ Endocrinol 1999; 140:505-11

17 Tsegaye B, Ergete W. Histopathologic pattern of thyroid disease. East Afr Med J 2003;80:525-8

18 Olurin EO, Itayemi SO, Oluwasanmi JO, Ajayi OO. The pattern of thyroid gland disease in Ibadan. Nig Med J 1973;3:58-65

19 Gitau W. An analysis of thyroid diseases seen at Kenyatta National Hospital. East Afr Med J 1975;52:564-70

20 Ermans AM, Delange F, Van der Velden M, Kinthaert J. Goitrogenic action of cyanogenic glucosides present in cassava: a possible etiologic 
factor of endemic goiter in the Idjwi island. Acta Endocrinol Suppl (Copenh) 1973;179:31

21 Thilly CH, Swennen B, Bourdoux P, Ntambue K, Moreno-Reyes R, Gillies J, et al. The epidemiology of iodine-deficiency disorders in relation to goitrogenic factors and thyroid-stimulating-hormone regulation. Am J Clin Nutr 1993;57(2 Suppl):267S-70S

22 Eltom M, Hofvander Y, Torelm I, Fellstrom B. Endemic goitre in the Darfur region (Sudan). Epidemiology and aetiology. Acta Med Scand 1984;215:467-75

23 Wyss K, Guiral C, Ndikuyeze A, Malonga G, Tanner M. Prevalence of iodine deficiency disorders and goitre in Chad. Trop Med Int Health 1996;1:723-9

24 Beasley M, Brooker S, Ndinaromtan M, Madjiouroum EM, Baboguel $\mathrm{M}$, Djenguinabe $\mathrm{E}$ et al. First nationwide survey of the health of schoolchildren in Chad. Trop Med Int Health 2002;7:625-30

25 Jooste PL, Langenhoven ML, Kriek JA, Kunneke E, Nyaphisi M, Sharp B. Nutritional status of rural children in the Lesotho Highlands. East Afr Med J 1997;74:680-9

26 Sebotsa ML, Dannhauser A, Jooste PL, Joubert G. Prevalence of goitre and urinary iodine status of primary-school children in Lesotho. Bull World Health Organ 2003;81:28-34

27 Jooste PL, Weight MJ, Lombard CJ. Short-term effectiveness of mandatory iodination of table salt, at an elevated iodine concentration, on the iodine and goiter status of schoolchildren with endemic goiter. Am J Clin Nutr 2000;71:75-80

28 WHO, UNICEF, ICCIDD. Review of Findings from 7-country Study in Africa on Levels of Salt Iodination in Relation to Iodine Deficiency Disorders, Including Iodine Induced Hyperthyroidism. Geneva: World Health Organization

29 Egbuta J, Onyezili F, Vanormelingen K. Impact evaluation of efforts to eliminate iodine deficiency disorders in Nigeria. Public Health Nutr 2003;6:169-73

30 Zimmermann MB, Hess SY, Adou P, Toresanni T, Wegmuller R, Hurrell RF. Thyroid size and goiter prevalence after introduction of iodized salt: a 5-y prospective study in schoolchildren in Côte d'Ivoire. Am J Clin Nutr 2003;77:663-7

31 Lagasse R, Luvivila K, Yunga Y, Gerard M, Hanson A, Bourdoux $\mathrm{P}$ et al. Endemic goitre and cretinism in Ubangi. In: Ermans AM, Mbulamoko NM, Delange F and Ahluwalia R, eds Role of Cassava in the Aetiology of Endemic Goitre and Cretinism. Ottawa, Canada: International Development Research Centre, IDRC 136e; 1980:45-60

32 Moreno-Reyes R, Boelaert M, el Badawi S, Eltom M, Vanderpas JB. Endemic juvenile hypothyroidism in a severe endemic goitre area of Sudan. Clin Endocrinol (Oxf) 1993;38:19-24

33 Delange F, Ermans AM, Vis HL, Stanbury JB. Endemic cretinism in Idjwi Island (Kivu Lake, Republic of Congo). J Clin Endocrinol Metab 1972;34:1059-66

34 Aguayo VM, Scott S, Ross J. Sierra Leone-investing in nutrition to reduce poverty: a call for action. Public Health Nutr 2003;6:653-7

35 Stanbury JB, Ermans AE, Bourdoux P, Todd C, Oken E, Tonglet R, et al. Iodine-induced hyperthyroidism: occurrence and epidemiology. Thyroid 1998;8:83-100

36 Todd $\mathrm{CH}$, Allain T, Gomo ZA, Hasler JA, Ndiweni M, Oken E. Increase in thyrotoxicosis associated with iodine supplements in Zimbabwe. Lancet 1995;346:1563-4
37 Bourdoux PP, Ermans AM, Mukalay WA Mukalay A, Filetti S, Vigneri R. Iodine-induced thyrotoxicosis in Kivu, Zaire. Lancet 1996;347:552-3

38 Delange F, de Benoist B, Alnwick D. Risks of iodine-induced hyperthyroidism after correction of iodine deficiency by iodized salt. Thyroid 1999;9:545-56

39 Vanderpump MP, Tunbridge WM, French JM, Appleton D, Bates D, Clark F, Grimley Evans J, Hasan DM, Rodgers H, Tunbridge F, et al. The incidence of thyroid disorders in the community: a twenty-year follow-up of the Whickham Survey. Clin Endocrinol (Oxf) 1995;43:55-68

40 Kalk WJ, Kalk J. Incidence and causes of hyperthyroidism in blacks. S Afr Med J 1989;75:114-17

41 Gelfand M. Thyrotoxicosis in the African: report of a case. Cent Afr J Med 1962;8:123-4

42 Joffe B, Gunji K, Panz V, Zouvanis M, Swanson J, Ackrell BA et al. Thyroid-associated ophthalmopathy in black South African patients with Graves' disease: relationship to antiflavoprotein antibodies. Thyroid 1998;8:1023-7

43 Zouvanis M, Panz VR, Kalk WJ, Joffe BI. Thyrotropin receptor antibodies in black South African patients with Graves' disease and their response to medical therapy. J Endocrinol Invest 1998;21:771-4

44 Kalk WJ. Atypical features of hyperthyroidism in blacks. S Afr Med J 1980;57:707-10

45 Boukis MA, Koutras DA, Souvatzoglou A, Evangelopoulou A, Vrontakis M, Moulopoulos SD. Thyroid hormone and immunological studies in endemic goiter. J Clin Endocrinol Metab 1983;57:859-62

46 Premawardhana LD, Parkes AB, Smyth PP, Wijeyaratne CN, Jayasinghe A, de Silva DG et al. Increased prevalence of thyroglobulin antibodies in Sri Lankan schoolgirls - is iodine the cause? Eur J Endocrinol 2000;143:185-8

47 Zimmermann MB, Moretti D, Chaouki N, Torresani T. Introduction of iodized salt to severely iodine-deficient children does not provoke thyroid autoimmunity: a one-year prospective trial in northern Morocco. Thyroid 2003;13:199-203

48 Feldt-Rasmussen U. Iodine and cancer. Thyroid 2001;11:483-6

49 Selzer G, Kahn LB, Albertyn L. Primary malignant tumors of the thyroid gland: a clinicopathologic study of 254 cases. Cancer 1977;40:1501-10

50 Thomas JO, Ogunbiyi JO.Thyroid cancers in Ibadan, Nigeria. East Afr Med J 1995;72:231-3

51 Bakiri F, Djemli FK, Mokrane LA, Djidel FK. The relative roles of endemic goiter and socioeconomic development status in the prognosis of thyroid carcinoma. Cancer 1998;82:1146-53

52 Omran M, Ahmed ME. Carcinoma of the thyroid in Khartoum. East Afr Med J 1993;70:159-62

53 Lawal O, Agbakwuru A, Olayinka OS, Adelusola K. Thyroid malignancy in endemic nodular goitres: prevalence, pattern and treatment. Eur J Surg Oncol 2001;27:157-61

54 Mulaudzi TV, Ramdial PK, Madiba TE, Callaghan RA. Thyroid carcinoma at King Edward VIII Hospital, Durban, South Africa. East Afr Med J 2001;78(5):242-5

55 Ketiku KK. Thyroid carcinoma in Nigeria: review of management. Eur J Surg Oncol 1990;16:443-7

56 Zimmermann MB, Wegmuller R, Zeder C, Torresani T, Chaouki N. Rapid relapse of thyroid dysfunction and goiter in school-age children after discontinuation of salt iodination. Am J Clin Nutr 2004;79:642-5 